\title{
Comparison between the 6-minute walk tests performed in patients with chronic obstructive pulmonary disease at different altitudes
}

\author{
Comparação entre os testes de caminhada de 6 minutos realizados em pacientes \\ com doença pulmonar obstrutiva crônica em diferentes altitudes
}

\author{
Selma Denis Squassoni ${ }^{1}$, Nadine Cristina Machado ${ }^{1}$, Mônica Silveira Lapa ${ }^{1}$, Priscila Kessar Cordoni ${ }^{1}$, \\ Luciene Costa Bortolassi ${ }^{1}$, Juliana Nascimento de Oliveira ${ }^{1}$, Cecilia Melo Rosa Tavares ${ }^{1}$, Elie Fiss ${ }^{1}$
}

\begin{abstract}
Objective: To evaluate the influence of the altitude on the 6-minute walking test in patients with moderate to severe pulmonary disease. Methods: Twenty-nine patients performed the 6-minute walk test at a pulmonary rehabilitation clinic in Santo André (above sea level), in São Paulo State, and at the Enseada Beach, in Guarujá (at sea level), also in São Paulo State. Of these 29 patients, 8 did the test both on hard sand and on asphalt to analyze if there were differences in performance during the tests. Data such as heart rate, oxygen saturation, test distance, and Borg scale were compared. Results: We found no statistical difference in relation to oxygen saturation at rest before the beginning of the walking test in Santo André $94.67 \pm 2.26 \%$ and at sea level $95.56 \pm 2 \%(p=0.71)$. The minimum saturation measured during the test was $87.27 \pm 6.54 \%$ in Santo André and $89.10 \pm 5.41 \%$ in Guarujá $(p=0.098)$. There were no differences in the performed distance between the different kinds of terrains; the distance on sand was $387.75 \pm 5.02 \mathrm{~m}$ and on asphalt it was $375.00 \pm 6.54 \mathrm{~m}(\mathrm{p}=0.654)$. Regarding oxygen saturation during walking, the pulse oximetry on sand was $95.12 \pm 1.80 \%$ and on asphalt it was $96.87 \pm 1.64 \%(p=1.05)$. Conclusion: Altitude did not affect the performance of the walking test in patients with moderate to severe pulmonary disease and the results were similar in both cases, on sand and on asphalt.
\end{abstract}

Keywords: Pulmonary disease, chronic obstructive/metabolism; Exercise test/methods; Exercise tolerance; Walking; Altitude

\section{RESUMO}

Objetivo: Avaliar a influência da altitude no teste de caminhada de 6 minutos em pacientes com doença pulmonar moderada a grave. Métodos: Vinte e nove pacientes realizaram o teste de caminhada de 6 minutos em um ambulatório de reabilitação pulmonar, na cidade de Santo André (acima do nível do mar), em São Paulo, e na praia da Enseada no Guarujá (ao nível do mar), também em São Paulo. Destes, oito pacientes realizaram tanto na areia batida como no asfalto, para avaliar a existência de alguma alteração no desempenho durante o teste. Dados como frequência cardíaca, saturação de oxigênio, distância do teste e escala de Borg foram comparados. Resultados: Não encontramos diferença estatística em relação à saturação de oxigênio em repouso antes do início do teste de caminhada em Santo André $94,67 \pm 2,26 \%$ e ao nível do mar $95,56 \pm 2 \%(p=0,71)$. A saturação mínima obtida durante os testes foi de $87,27 \pm 6,54 \%$, em Santo André, e de $89,10 \pm 5,41 \%$, no Guarujá $(p=0,098)$. Não houve diferença na distância percorrida e nos diferentes tipos de piso; a distância na areia foi de $387,75 \pm 5,02 \mathrm{~m}$ e $375,00 \pm 40,88 \mathrm{~m}$ no asfalto $(p=0,654)$. Quanto à saturação durante a caminhada, a oximetria de pulso na areia foi de $95,12 \pm 1,80 \%$ e no asfalto foi de $96,87 \pm 1,64 \%$ ( $p=1,05)$, ou seja, 0 teste foi reprodutível em ambos os solos. Conclusão: $A$ altitude não influenciou o desempenho do teste de caminhada realizado por pacientes com doença pulmonar moderada a grave, sendo reprodutível tanto acima quanto ao nível do mar, mesmo realizado em areia batida ou no asfalto.

Descritores: Doença pulmonar obstrutiva crônica/metabolismo; Teste de esforço/métodos; Tolerância ao exercício/métodos; Caminhada; Altitude

\footnotetext{
Faculdade de Medicina do ABC, Santo André, SP, Brazil.

Corresponding author: Selma Denis Squassoni - Avenida Príncipe de Gales, 821 - Príncipe de Gales - Zip code: 09060-650 - Santo André, SP, Brazil - Phone: (55 11) $4438-3558$ E-mail: selma_denis@yahoo.com.br

Received on: June 25, 2014 - Accepted on: Oct 10, 2014

Conflict of interest: none.

DOI: 10.1590/S1679-45082014A03139
} 


\section{INTRODUCTION}

Individuals with chronic obstructive pulmonary disease (CPOD) may present with a significant reduction in physical capacity due to various factors, such as dynamic hyperinflation and progressive physical deconditioning associated with inactivity, ${ }^{(1)}$ leading to physical and social limitations, which cause deterioration in their quality of life. (2)

Resulting from these alterations, evaluation of physical capacity or of the capacity for exercise in individuals with CPOD became the goal of many studies. The causes of physical exercise intolerance in patients with CPOD are traditionally focused on the limitations of the ventilatory system (gas exchange), ${ }^{(3,4)}$ in functional abnormalities (such as reduced strength and resistance), and in muscular bioenergy (such as reduced oxygen uptake) ${ }^{(5-7)}$

In order to evaluate physical capacity of patients with CPOD, the 6-minute walk test (6MWT) is used, which more accurately reflects the limitations to Daily Life Activities and is more sensitive than treadmill tests. $^{(8)}$ Individuals with CPOD present with reduced tolerance to exercise, ${ }^{(9,10)}$ associated with a feeling of dyspnea and fatigue, and suffer reduction of functional capacity upon exercise with the progression of the disease. ${ }^{(9)}$ Studies performed at the Dead Sea showed that patients with CPOD showed an increase in the distance covered during the 6MWT, with less dyspnea and improved functional capacity at lower altitudes. ${ }^{(11-16)}$

The effects of altitude on pulmonary physiology are a result, basically, of decreased atmospheric pressure. As the altitude we are exposed to increases, there is a decrease in atmospheric pressure and consequently, a drop in the partial pressure of oxygen in the environment. ${ }^{(17)}$ Nevertheless, the interference in the variation of 6MWT at different altitudes is still not well established, such as, for example, between the city of Santo André (São Paulo) and at sea level.

The initial hypothesis of the study was that the patients with moderate to severe chronic obstructive pulmonary disease would have a better performance at sea level during the 6-minute walking test, regardless of the type of soil.

\section{OBJECTIVES}

To evaluate the influence of altitude on the 6-minute walk test in patients with chronic obstructive pulmonary disease, moderate to severe, and the performance of the patients on different soils, such as hard sand and asphalt.

\section{METHODS}

This is a retrospective study in which 29 patients were analyzed, 19 of them women. The mean age of patients was $66.41 \pm 10.55$ years, with a forced expiratory volume in the first second (FEV1), in percentage, of $50.56 \pm 14.81 \%$, and body mass index (BMI) of $25.9 \pm 5.9$. The subjects had moderate to severe CPOD, according to GOLD, ${ }^{(18)}$ in which 17 were moderate and 12 were severe cases (Table 1).

Table 1. Demographic characteristics of the sample

\begin{tabular}{lc}
\hline Characteristics & $\mathbf{n}$ \\
\hline Gender & 10 \\
Male & 19 \\
Female & \\
Age, years & 66.41 \\
Mean & 14.81 \\
Standard deviation & \\
BMI, m/kg & \\
Mean & 25.9 \\
Standard deviation & 5.9 \\
Post-baseline FEV1 & \\
Mean & 50.56 \\
Standard deviation & 14.81 \\
CPOD & \\
Moderate & 17 \\
Severe & 12 \\
\hline BMI: body mass index; FEV1: forced expiratory volume in the first second; CPOD: chronic obstructive pulmonary \\
disease.
\end{tabular}

The patients carried out the 6MWT at the Pulmonary Rehabilitation Outpatient Clinic of the Faculdade de Medicina do $A B C$, in the city of Santo André (above sea level $-760 \mathrm{~m}$ ), in São Paulo, and on the Enseada beach, in Guarujá (at sea level $=0 \mathrm{~m}$ ), which is also in the state of São Paulo. The test was done as per the guidelines of the American Thoracic Society (ATS) ${ }^{(19)}$ on a 30-meter marked lane. The 6MWT was done during an external activity, which was included in the Pulmonary Rehabilitation Program (PRP) as standard procedure of the facility during the period from October, 2012, to April, 2014. The project was approved by the Research Ethics Committee of the Faculdade de Medicina do ABC (CAAE No.: 06661712.3.0000.0082), and all patients signed the Informed Consent Form.

The study included patients with moderate to severe CPOD, with FEV1 between $30 \%$ and $<80 \%$, ${ }^{(18)}$ who were clinically stable and under adequate treatment for the degree of illness and under follow-up with a pneumologist. Excluded were clinically unstable patients 
who had had exacerbations within the previous 3 months, incapable of walking (musculoskeletal or neurological limitations) and with severe cardiac disease and/or requiring the use of oxygen.

Patients performed the 6MWT one hour after arriving at the beach, as per the ATS guidelines, ${ }^{(19)}$ with no adaptation period. Before and after the tests, parameters such as systolic (SBP) and diastolic (DBP) blood pressure, heart rate (HR), oxygen saturation $\left(\mathrm{SaO}_{2}\right)$, and Borg scale ${ }^{(20)}$ for dyspnea and lower limb fatigue were checked. However, for purposes of safety and better monitoring of the subjects, $\mathrm{SaO}_{2}, \mathrm{HR}$, and Borg's scale were measured every minute until the end of the test. After completing the 6MWT, the distance that each individual had covered during the test was recorded. All the parameters and distances were compared between the tests done above sea level and at sea level. To check $\mathrm{SaO}_{2}$ and $\mathrm{HR}$, a digital finger Onyx ${ }^{\circledast}$, model 9500 (Nonin) pulse oximeter was used (Medical, Inc. Minneapolis, MN, USA). During this activity, the patients were followed by pneumologists, physical therapists, and a licensed professional nurse (LPN) trained for emergency measures.

A total of 29 patients participated in the study. Among them, eight patients did the test on the beach with an irregular surface (hard sand) and on asphalt on two different days, with the purpose of evaluating their performance on different terrains.

The data obtained from the total sample $(n=29)$ during the tests, such as $\mathrm{SaO}_{2}$ and the distance of the $6 \mathrm{MWT}$, were compared and correlated. The paired t-test and correlation between them and all the variables performed above sea level, at sea level, and on different surfaces of the beach (distance, $\mathrm{SaO}_{2}$, and Borg's scale) were analyzed. For analysis of the Borg scale, maximum dyspnea, and lower limb fatigue, in Santo André and on the beach, the $\chi^{2}$ test was used. The only variables analyzed in the eight patients who did the tests on the sand and on the asphalt were the 6MWT distance and $\mathrm{SaO}_{2}$ during the tests, since the sample was small and $\chi^{2}$ test could not be done. The results were obtained with means and standard deviations. The sample normality test (even knowing that it should be done with larger samples) was performed and we chose to use the paired $t$-test, since the same sample was compared in different situations. The calculation of $r$ was done by Pearson's test.

\section{RESULTS}

No differences were found between the $\mathrm{SaO}_{2}$ at rest during the 6MWT at the Outpatient Clinic in Santo André $(94.76 \pm 2.26 \%)$ and at the Enseada beach $(95.54 \pm 2 \%$; $\mathrm{p}=0.71$ ). The minimum $\mathrm{SaO}_{2}$ found during the tests was $87.28 \pm 6.54 \%$, in Santo André, and $89.10 \pm 5.41 \%$, in Guarujá $(\mathrm{p}=0.098)$ (Table 2).

There was no statistical difference in the distances during the 6MWT performed on the beach and at the altitude in Santo André. On the beach, there was a mean of $428.31 \pm 55.91 \mathrm{~m}$, and in Santo André, 413.17 $\pm 60.8 \mathrm{~m}$ $(\mathrm{p}=0.178)$, that is, the patients were capable of reproducing the test at different altitudes $(\mathrm{r}=0.49 ; \mathrm{p}=0.007)$ (Table 2$)$ (Figure 1).

Table 2. Mean variables of the 6-minute walk test at different altitudes

\begin{tabular}{|c|c|c|c|c|c|c|c|c|c|}
\hline \multirow[b]{2}{*}{ Altitude } & \multicolumn{3}{|c|}{ Distance 6MWT, m } & \multicolumn{3}{|c|}{ Baseline $\mathrm{SaO}_{2}, \%$} & \multicolumn{3}{|c|}{$\mathrm{SaO}_{2} \min , \%$} \\
\hline & Mean & $\begin{array}{l}\text { Standard } \\
\text { deviation }\end{array}$ & $\begin{array}{c}\mathbf{p} \\
\text { value }\end{array}$ & Mean & $\begin{array}{l}\text { Standard } \\
\text { deviation }\end{array}$ & $\begin{array}{c}\mathbf{p} \\
\text { value }\end{array}$ & Mean & $\begin{array}{l}\text { Standard } \\
\text { deviation }\end{array}$ & $\begin{array}{c}p \\
\text { value }\end{array}$ \\
\hline $\begin{array}{l}\text { Above sea } \\
\text { level }=760 \mathrm{~m}\end{array}$ & 428.31 & 54.94 & 0.178 & 94.76 & 2.22 & 0.71 & 87.28 & 6.43 & 0.098 \\
\hline $\begin{array}{l}\text { At sea } \\
\text { level }=0 \mathrm{~m}\end{array}$ & 413.17 & 59.78 & & 95.54 & 1.97 & & 89.10 & 5.32 & \\
\hline
\end{tabular}

$\mathrm{SaO}_{2}$ : oxygen saturation; 6MWT: 6-minute walk test.

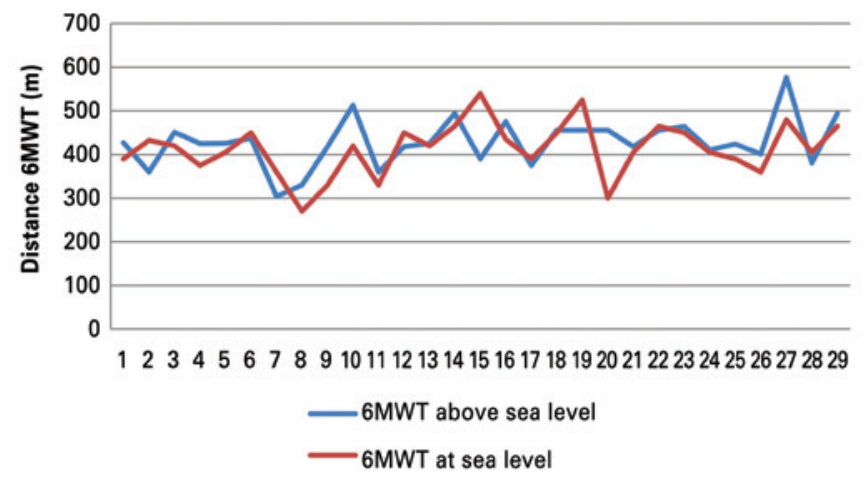

6MWT: 6-minute walk test.

Figure 1. Comparison of the distance covered in the 6-minute walk test at different altitudes $(n=29)$

A sample of eight patients performed the 6MWT on the beach and on the asphalt and there was no difference as to the distance covered between the types of terrain (distance of $387.75 \pm 5.02 \mathrm{~m}$ on the sand and $375.00 \pm 40.88 \mathrm{~m}$ on the asphalt; $\mathrm{p}=0.654$ ). During the walk on the sand, the $\mathrm{SaO}_{2}$ was $95.54 \pm 1.97 \%$ and on asphalt, $96.88 \pm 1.54 \%(\mathrm{p}=1.05)$, that is, the test is reproducible on both surfaces (Table 3 ) (Figure 2).

For the maximum Borg value of dyspnea, there were no differences in $\chi^{2}$ test between the two situations $(\mathrm{p}=0.3)$, just as we found no significant difference relative to the maximum Borg value for lower limb fatigue $(p=0.55)$, that is, the feeling of dyspnea and lower limb fatigue was similar at the different altitudes (Table 4). 
Table 3. Mean variables of the 6-minute walk test on different types of soil at the beach

\begin{tabular}{lcccccccc}
\hline & \multicolumn{3}{c}{ Distance 6MWT (m) } & & \multicolumn{3}{c}{ Baseline Sa0 } \\
\cline { 3 - 4 } Types of soil & Mean & $\begin{array}{c}\text { Standard } \\
\text { deviation }\end{array}$ & $\begin{array}{c}\mathbf{p} \\
\text { value }\end{array}$ & & Mean & $\begin{array}{c}\text { Standard } \\
\text { deviation }\end{array}$ & $\begin{array}{c}\mathbf{p} \\
\text { value }\end{array}$ \\
\hline Asphalt & 375 & 38.24 & 0.654 & & 96.88 & 1.54 & 1.05 \\
Beach sand & 387.75 & 5.02 & & & 95.54 & 1.97 & \\
\hline
\end{tabular}

$\mathrm{SaO}_{2}$ : oxygen saturation; 6MWT: 6-minute walk test.



6MWT: 6-minute walk test.

Figure 2. Comparison of the distance covered in the 6-minute walk test on different surfaces $(n=8)$

Table 4. Data from the Borg scale ${ }^{(20)}$ - dyspnea and fatigue of lower limbs

\begin{tabular}{lccc}
\hline Borg Scale & $\begin{array}{c}\text { Santo André } \\
(\mathbf{n = 2 9 )}\end{array}$ & $\begin{array}{c}\text { Beach } \\
(\mathbf{n = 2 9 )}\end{array}$ & $\begin{array}{c}\text { Asphalt } \\
(\mathbf{n = 8})\end{array}$ \\
\hline Borg maximum dyspnea & 7 & 7 & 5 \\
Borg maximum fatigue of lower limbs & 5 & 5 & 5 \\
Borg minimum dyspnea & 0 & 0 & 0 \\
Borg minimum fatigue of lower limbs & 0 & 0 & 0 \\
\hline
\end{tabular}

\section{DISCUSSION}

Patients with CPOD usually report that at sea level, the feeling of dyspnea is less than in the city of Santo André. The tests at both altitudes were reproducible, that is, they had the same performance both at sea level and at $760 \mathrm{~m}$ altitude (similar results), regardless of the ground used.

The patients showed no difference in the distance between the 6MWT at the different altitudes evaluated or for the different types of surfaces, but a study that evaluated energetic and mechanical output of individuals who run and walk in the sand, demonstrated that walking and running in the sand requires 1.6-2.5 times more effort than on a firm surface.(21) Whereas a study performed at the Dead Sea in patients with CPOD showed an increase in distance of the 6MWT from $112 \mathrm{~m}$ after remaining for a week at an altitude of $417 \mathrm{~m}$ below sea level, and of $170 \mathrm{~m}$ after three weeks. One week after returning to Jerusalem, they continued with an increase in distance covered of $116 \mathrm{~m}$. In our study, we did not obtain this difference, but we should consider that the time that these patients remained at sea level was too short for there to be some alteration in 6MWT. ${ }^{(12)}$ Additionally, the difference in altitude was smaller (in meters) than in the study mentioned. The 6MWT is an important test for evaluating the physical capacity of individuals with functional limitation, in whom the assessment should be useful for quantifying the severity of this limitation and the results of treatment. The individuals with CPOD presented with reduced tolerance to exercise, ${ }^{(9)}$ associated with feeling dyspnea and fatigue, and suffer a reduction in functional capacity for exercise with the progression of the disease. ${ }^{(10)}$

We found no differences between the $\mathrm{SaO}_{2}$ at rest during the walking tests and at minimal saturation between the different altitudes. On the other hand, in the study performed at the Dead Sea, in Jerusalem, the patients presented with a decrease from 88 to $84 \%$ in $\mathrm{SaO}_{2}$ at the end of the walk. At the Dead Sea, this decrease was from 92 to $86 \%$ after one week, and from 93 to $83 \%$ after three weeks. ${ }^{(12)}$ Also, another study ${ }^{(13)}$ carried out at the Dead Sea, suggested that all the patients felt less dyspnea and reported improved functional capacity and lower need for oxygen. It is possible that the time of stay at lower altitudes influenced the results obtained and it may be necessary to remain for at least one week at lower altitudes to evaluate the differences in physical capacity after this period of adaptation.

Patients with CPOD presented with difficulty in socialization and leisure, did not accompany family members to social events, that is, they isolated themselves and quit participating in performing tasks and abandoning their activities. ${ }^{(22)}$ It is important to realize that when a person is diagnosed with CPOD, he/she should necessarily modify his/her lifestyle, seeking better quality of life.(23) To stimulate social contact, as well as to promote the outing of these patients at the beach, is part of our PRP, with the objective of improving their quality of life and their integration with society.

Some limitations might have influenced the results of the present study, such as the short time of permanence at sea level, the greater distance between the altitudes studied, and the small size of the sample. As an objective of a future project, it would be interesting to follow this line of research and study patients who remain at least one week at sea level.

\section{CONCLUSION}

The altitude did not influence the performance of the patients with moderate to severe chronic obstructive pulmonary disease during the 6-minute walk test. The results of the variables analyzed were similar, both at sea level and at the altitude of the city of Santo André (760m). 
The analysis of the performance related to the difference surfaces also showed no significant difference in the 6-minute walk test performed on the asphalt or on hard sand, and it would be necessary to carry it out with a larger sample.

\section{REFERENCES}

1. Marin JM, Carrizo SJ, Gascon M, Sanchez A, Gallego B, Celli B. Inspiratory capacity, dynamic hyperinflation, breathlessness and exercise performance during the 6-minutes-walk test in chronic obstructive pulmonary disease. Am J Respir Crit Care Med. 2001;163(6):1395-9.

2. Knox AJ, Morrison JF, Muers MF. Reproducibility of walking test results in chronic obstructive airways disease. Thorax. 1988;43(5):388-92.

3. Dias LR, Maganhoto TF, Nonaka PN, Magnani RM, Osório RA, Reis CT. Análise do lactato em indivíduos portadores de DPOC com e sem técnicas de conservação de energia. [X Encontro Latino Americano de Iniciação Científica e VI Encontro Latino Americano de Pós-graduação] - Universidade do Vale do Paraíba. [citado 2014 Jul 21]. Disponível em: [http://www.scielo.oces. mctes.pt/scielo.php?pid=S0873-21592009000600008\&script =sci_arttext]

4. Dourado VZ, Godoy I. Recondicionamento muscular na DPOC: Principais intervenções e novas tendências. Rev. Bras Med Esporte. 2004;10(4):331-4.

5. Silva KR, Marrara KT, Marino DM, Di Lorenzo VA, Jamami M. Fraqueza muscular esquelética e intolerância ao exercício em pacientes com doença pulmonar obstrutiva crônica. Rev Bras Fisioter. 2008;12(3):169-75.

6. Dourado VZ, Tanni SE, Vale SA, Faganello MM, Sanchez FF, Godoy I. Manifestações sistêmicas na doença pulmonar obstrutiva crónica. J Bras Pneumol. 2006;32(2):161-71.

7. Rodrigues SL, Viegas CA, Lima T. Efetividade da reabilitação pulmonar como tratamento coadjuvante da doença pulmonar obstrutiva crónica. J Pneumol. 2002;28(2):65-70.

8. Poulain M, Durand F, Palomba B, Ceugniet F, Desplan J, Varray A, et al. Six minute walk testing is more sensitive than maximal incremental cycle testing for detecting oxygen desaturation in patients with COPD. Chest. 2003;123(5):1401-7.

9. Solway S, Brooks D, Lau L, Goldstein R. The short-term effect of a rollator on functional exercise capacity among individuals with severe COPD. Chest 2002;122(1):56-65.

10. Rodrigues SL, Viegas CA, Lima T. Efetividade da reabilitação pulmonar como tratamento coadjuvante da doença pulmonar obstrutiva crônica. J Pneumol. 2002;28(2):65-70.

11. Kramer MR, Springer C, Berkman N, Glazer M, Bublil M, Bar-Yishay E, et al. Rehabilitation of hypoxemic patients with COPD at low altitude at the Dead Sea, the lowest place on earth. Chest. 1998;113(3):571-5.

12. Kramer MR, Springer C, Berkman N, Bar-Yishay E, Avital A, Mandelberg A, et al. Effect of natural oxygen enrichment at low altitude on oxygen-dependent patients with end-stage lung disease. Ann Intern Med. 1994;121(9):658-62.

13. Van Stel HF, Bogaard JM, Rijssenbeek-Nouwens LH, Colland VT. Multivariable assessment of the 6-min walking test in patients with chronic obstructive pulmonary disease. Am J Respir Crit Care Med. 2001;163(7):1567-71.

14. Rodrigues SL, Viegas CA. Estudo de correlação entre provas funcionais respiratórias e o teste de caminhada de seis minutos em pacientes portadores de doença pulmonar obstrutiva crônica. J Pneumol. 2002;28(6):324-8.

15. Moreira MA, Moraes MR, Tannus R. Teste da caminhada de seis minutos em pacientes com DPOC durante programa de reabilitação. J Pneumol. 2001;27(6):295-300.

16. Solway $S$, Brooks D, Lacasse $Y$, Thomas $S$. A qualitative systemic overview of the measurement properties of functional walk tests used in the cardiorespiratory domain. Chest. 2001;119(1):256-70.

17. Carvalho CR. Fisiopatologia respiratória. São Paulo: Atheneu; 2005.

18. Global Initiative for Chronic Obstructive Lung Disease - COPD 2014 Global Strategy for Diagnosis, Management, and Prevention of COPD (UPDATED 2014) (http:www.goldcopd.org).

19. American Thoracic Society. ATS statement: guidelines for the six-minutes walk test. Am J Respir Crit Care Med. 2002;166(1):111-7.

20. Borg GA. Psychophysical bases of perceived exertion. Med Sci Sport Exerc. 1982;14(5):377-81.

21. Lejeune TM, Willems PA, Heglund NC. Mechanics and energetics of human locomotion on sand. J Exp Biol. 1998;201(3):2071-80.

22. Fiks IN. DP... 0 quê? São Paulo: Claridade; 2005. p. 152-5.

23. Kerkoski E, Borenstein MS, Gonçalves LO, Francioni FB. Grupo de convivência com pessoas com doença pulmonar obstrutiva crônica: sentimentos e expectativas. Texto \& Contexto Enferm. 2007:16(2):225-32. 